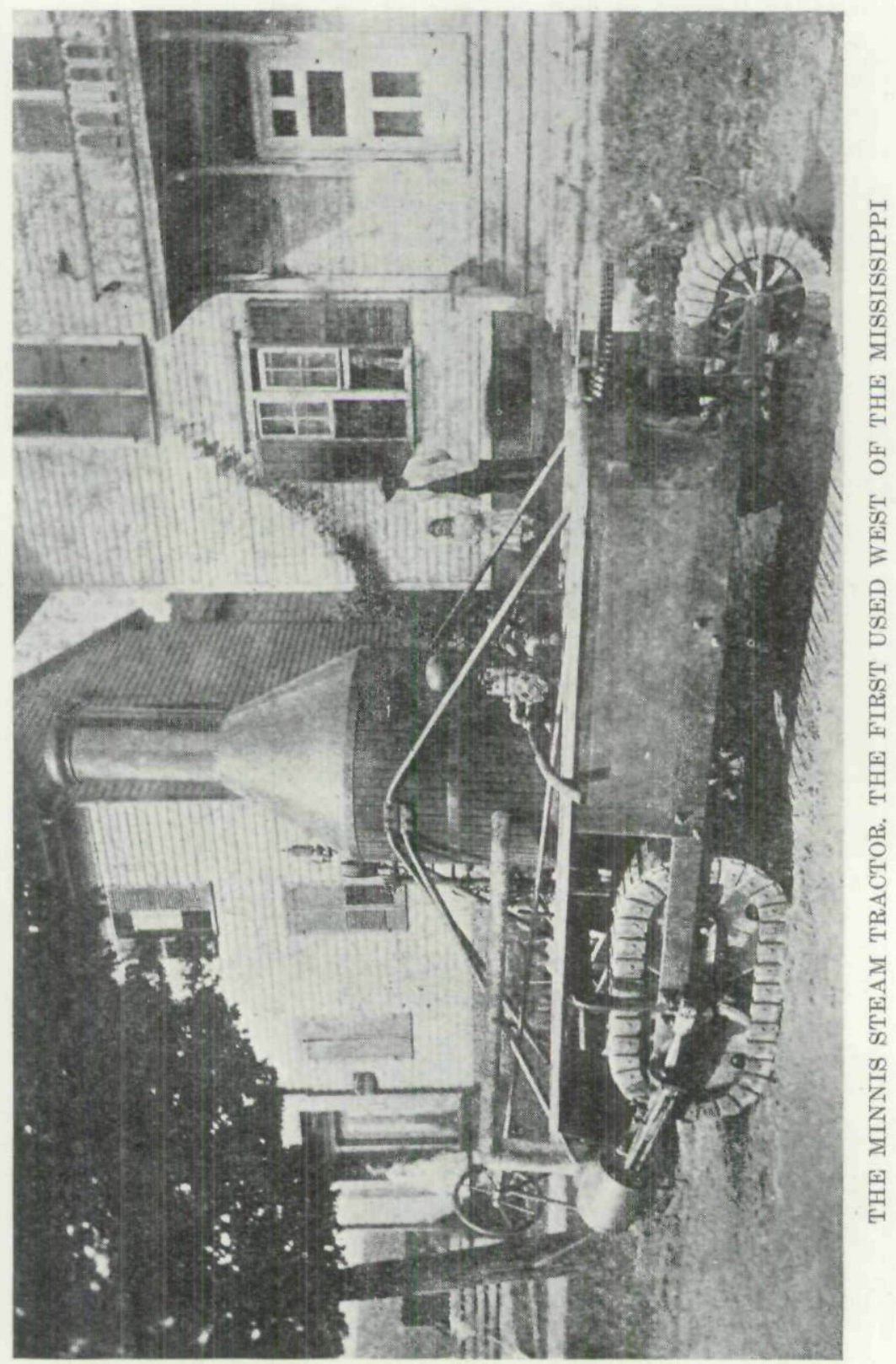




\title{
IOWA'S FIRST STEAM TRACTOR
}

\author{
By F. Hal Higgins
}

Prophetic of a new day in agriculture was the year 1869 . That fall the state agricultural school at Ames first opened its doors to regular classes, thus beginning the service of serious study of the problems of agriculture which has since yielded untold benefits. Also in 1869, with the completion of the second trans-Iowa railroad to Council Bluffs and the rapid extension of other main lines and their linking branches, the middle west was finding new markets for their grains. Moreover the railroads by bringing new hordes of emigrants from Europe to the fertile prairies made additional demands upon the extensive cultivation of the grains, the tilling of the soil. Thus it was hardly a coincidence that among the trails of smoke which smudged the horizons of Iowa was one which, though it attracted less attention from the railroadhungry Iowa settlers, was nevertheless closely linked with the future of agriculture. The slower moving smoke signal was from the "Steam Plow" that Thomas S. Minnis of Meadville, Pennsylvania, had brought out to the prairies of Iowa to prove that his invention could break the virgin sod for wheat raising more economically than could oxen or horses. It was Iowa's first dirt farming tractor and it proved a paradox in being a "success" and a failure at the same time. It worked but there were no farmers with financial rating high enough to buy and operate it.

The writer's researches into tractor history have but recently brought to light a picture of this machine and its inventor who over seventy years ago pioneered tractor farming in the Hawkeye state. With countless county historical societies, agricultural associations, and libraries striving to locate the story and picture of this historic machine, the answers only recently eame from Pennsylvania and California sources. The Iowa State Department of History and Archives turned up the 1869 Report of the Iowa State Agricultural Society, which gave Mr. P. C. Compton's story of the Minnis steam outfit as he had watched it work in 


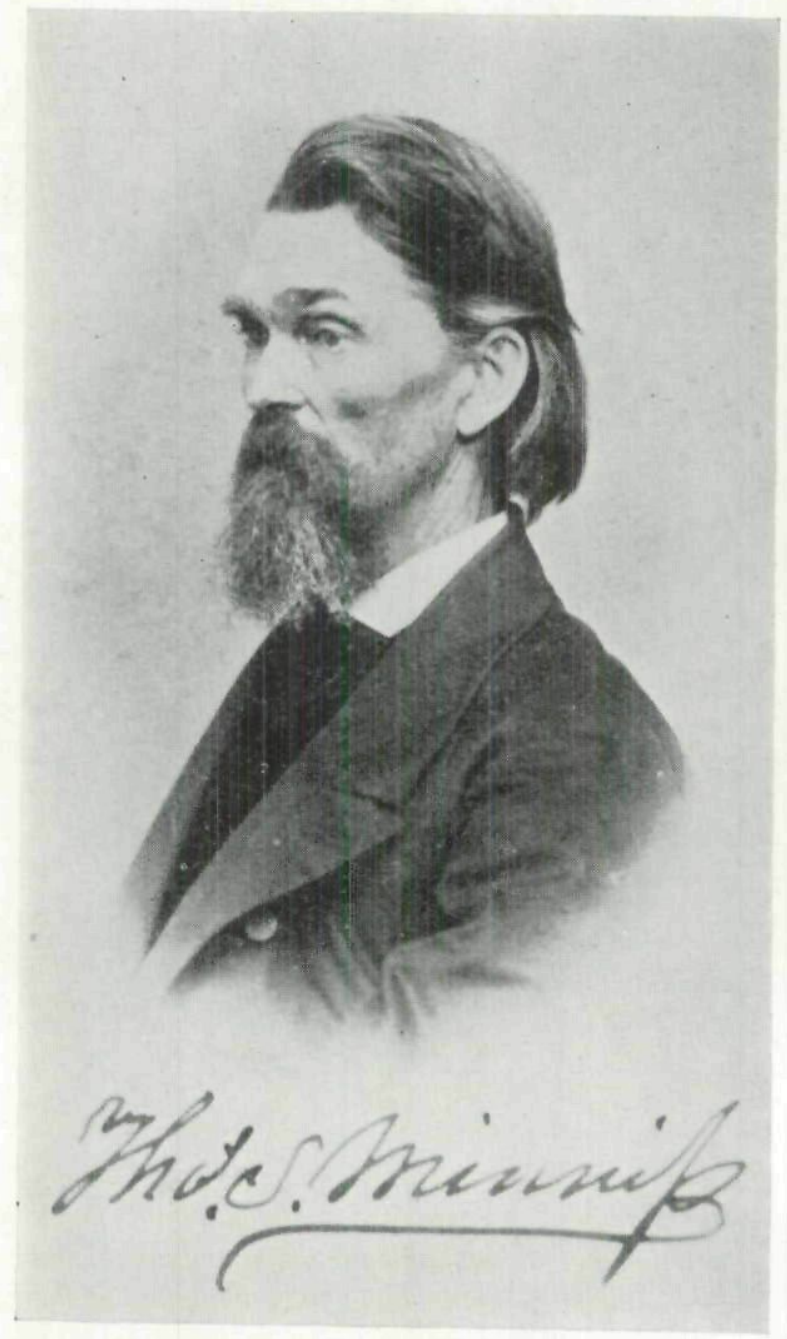

THOMAS S. MINNIS INVENTOR OF IOWA'S FIRST STEAM TRACTOR 
Iowa after its arrival just before Christmas, 1868. The Associate Editor of Pennsylvania Farmer turned to a friend in Meadville, Pennsylvania, for information on the Minnis family. That brought a letter from the last surviving daughter of Thomas S. Minnis, Mrs. Lida Minnis Brown of Los Angeles, who supplied the aceompanying photographs. Mrs. Brown recalls quite elearly her father's invention and his Iowa steam plowing adventures, as she entered Allegheny College, Pennsylvania, the year after it opened in 1870 , being graduated in 1875 .

Searches through the files of Iowa newspapers of 1869 and 1870 revealed no items about this remarkable machine that at Ames was making pioneer tractor history as the first tractor to do farm work between the Mississippi River and California and the first track-type tractor to attempt farm work west of Albany, New York. Perhaps there are a few older readers of this magazine who lived in Story County in 1869 and who saw the machine and can recall how long it worked there under Mr. Compton's direction. The Compton report that appeared in the state agricultural society's annual report, two paragraphs of which were repeated in the U.S. Department of Agriculture Report of 1870, would indicate it was still there in November. Hence, it may have worked two seasons and engaged in "custom" work for various land owners at so much per acre. Whether it was burning wood or eoal is not certain, though probably wood, as Compton's report suggests a larger fire box would have made it more efficient.

In England and France, and on some of the great landed estates of other countries, steam plows were being everywhere introduced for plantation and farm work. Pietures of their trials, or what we eall demonstrations today, show groups of well-fed and correctly dressed gentlemen with their ladies in bustling silks, making the affairs social events of note. In the United States, on the other hand, the wealthy landlord was replaced by the homesteading farmer in homespun elothes, working a quarter section of land with a team of oxen or horses, a wagon and a walking plow. It was men such as these who doubtless formed the larger part of the 
curious erowd that attended the trial, or demonstration of the Minnis plow deseribed below. The seventy-one year gap between tractor models of 1869 and 1940 is well suggested in the letter found on pages 306-308 in the Agricultural Society's Report for 1869 :

Ames, Iowa, Nov. 20, 1869

Mr. Secretary :

In response to your request, I will briefly outline my experience in an enterprise to plow by steam. From the necessities of the ease I am restricted both as to time and space, a juncture not conducive to good performance, were there no other disabilities.

On the 15th of January, 1867, Thos. S. Minnis, of Meadville, Pa., took out letters patent for a Locomotive for Plowing, ete. Two small machines were built and experimented with, one of them being three or four horse-power. We were so thoroughly convinced that we were on the right track, that we concluded to build a practical machine, 15 horse-power, and take it to the prairies, its natural working place. Accordingly the machine now here was built at Erie, Pa., and shipped to Iowa in December, 1868; nearly two years after the patent was taken out. Two years of such hard labor, diseouragements, dissappointments, and delays as few men ever experience.

This machine consists of a boiler, an engine on each side working on the same shaft, a quarter apart after the manner of railroad locomotives and the usual connections, all resting on two runners, six feet apart and nearly eight feet long, something like a sled. These runners glide over rollers, fixed in endless chain tracks. These tracks revolve in an ellipse, and the drive wheels move the chains and propel the machine forward or backward by the same motion. Either side may be run independently of the other. By this means, when drawing a load, it is easily turned or guided. When ready for work its weight is about eight tons. The width of the endless chain tracks is one foot, giving a contact with the ground of about 2,300 square inches, and a "traction" power limited only by weight.

Trial and Results-Last spring we prepared for our grand experiment. We attached five fourteen inch breaking plows in a solid frame, so guaged as to turn an aggregate of a little over six feet. We ran out on the prairie, a erowd following to see the machine sink in the first slough. They were disappointed. It rode across more lightly, or with less impression than did the empty wagons which followed. It drew the five ploughs through the toughest prairie sod, frequently beam deep, up and down grade, and through hard and soft ground. The "traction", power of the machine was not fully tested. It frequently drew the ploughs with only one side in gear, showing this power to be equal to drawing twice as many ploughs. In this respect, it filled what Prof. Brainard, in his excellent "History of American 
Inventions for Cultivation by Steam," pronounces the great want of all machines heretofore tried. It rode over dead furrows, ditches, and rough places as smoothly as a sled, touching only the highest points. It ran over ploughed ground with scarcely an appreciable increase of power. It was under perfect control, could be moved either way to an inch. In short, it run easier, proved stronger, and performed every way, in the main, better than was anticipated, and in the essential necessities of such a machine, is a success.

Then why, you ask, are results not greater 9 You and everybody else, I apprehend, are expecting too much from the steam plow. Prepare a place for the plow locomotive to work on, with a tithe of the pains and expense that is bestowed on the track for railroad locomotion and then look for commensurate results. Again, inventors are not famed for following up inventions to pecuniary profit, even after the idea has been developed into successful shape. Purse strings, like eamel's backs, are vincible, and enterprises pendent thereon often fail from very light causes. Add to these hinted moral and pecuniary deficits, the mechanical deficiencies which I will name, and you have the answer. These were, more strictly speaking, a disproportion of parts. A firebox disproportionately small. The elutches by which we guided the machine, too coarse, so that we could not make our variations nice enough. Of course there are numerous defects, but all may be easily remedied in the next machine.

We found generally, that it may be worked nearly as well on small fields as large ones; that two men ean run it; that weight is no detriment; hence plenty of power may be insured in larger boilers.

Hoping, Mr. Secretary, these few hasty hints in this matter may help some one in the grand endeavor to plough by steam, and thereby dignify and lighten the labors of agriculture, I remain,

Yours, most truly

P. C. Compton 
Copyright of Annals of Iowa is the property of State of Iowa, by \& through the State Historical Society of Iowa and its content may not be copied or emailed to multiple sites or posted to a listserv without the copyright holder's express written permission. However, users may print, download, or email articles for individual use. 